\title{
Evaluation of susceptibility of potential rape pathogens to selected essential oils
}

\section{Ocena wrażliwości potencjalnych patogenów rzepaku na wybrane olejki eteryczne}

\author{
Katarzyna Sadowska*, Natalia Łukaszewska-Skrzypniak, Jagoda Wojczyńska, \\ Sylwia Stępniewska-Jarosz, Małgorzata Tyrakowska, Maria Rataj-Guranowska
}

\begin{abstract}
Summary
The effect of selected essential oils on rape pathogens such as Sclerotinia sclerotiorum, Phoma lingam, Rhizoctonia solani and Fusarium oxysporum was estimated in vitro studies. S. sclerotiorum showed the lowest susceptibility to the examined essential oil treatments. The thyme oil displayed the highest fungistatic effect and suppressed the culture growth of all tested fungal species when applied at the concentration of 0.2 and $0.02 \%$. The lemongrass oil applied at the concentration of 0.2 and $0.02 \%$ inhibited the culture growth of the examined species from 90 to $100 \%$. The tea tree and grapefruit essential oils applied and the concentration less than $0.2 \%$ showed poor effectiveness or no fungistatic effect on $F$. oxysporum and S. sclerotiorum.
\end{abstract}

Key words: essential oils; fungistatic activity; biological control; rape pathogens

\section{Streszczenie}

W warunkach in vitro określano wpływ wybranych olejków eterycznych na wzrost liniowy grzybów, którym przypisuje się cechy patogenów rzepaku: Sclerotinia sclerotiorum, Phoma lingam, Rhizoctonia solani i Fusarium oxysporum. Spośród badanych grzybów najmniej wrażliwy na aplikację olejków do pożywki okazał się gatunek Sclerotinia sclerotiorum. Najsilniejszymi właściwościami fungistatycznymi odznaczał się olejek tymiankowy. Jego obecność w podłożu w stężeniu 0,2 i 0,02\% przyczyniła się do zahamowania w 100\% wzrostu wszystkich testowanych grzybów. Olejek z trawy cytrynowej w stężeniu 0,2 i 0,02\% hamował wzrost testowanych grzybów w zakresie od 90 do 100\%. Najmniej skuteczne były olejki grejpfrutowy i z drzewa herbacianego, które nie wykazywały właściwości fungistatycznych wobec $F$. oxysporum i S. sclerotiorum w stężeniu poniżej 0,2\%.

Słowa kluczowe: olejki eteryczne; aktywność fungistatyczna; biologiczna ochrona; patogeny rzepaku

\footnotetext{
Instytut Ochrony Roślin - Państwowy Instytut Badawczy

Władysława Węgorka 20, 60-318 Poznań

*corresponding author: k.sadowska@iorpib.poznan.pl
} 


\section{Wstęp / Introduction}

Wszechstronne wykorzystanie rzepaku jako surowca w przemyśle spożywczym, farmaceutycznym, kosmetycznym, energetycznym oraz w produkcji mieszanek paszowych powoduje, że powszechnie uprawia się go na świecie i w Polsce (Banaszkiewicz i Borkowska 2006). Co roku obserwuje się kilkunastoprocentowe straty w plonie rzepaku spowodowane nasileniem objawów chorób powodowanych przez grzyby. Średnie straty ilościowe plonu nasion rzepaku wynikające $\mathrm{z}$ infekcyjnego charakteru sprawców chorób wynoszą około 15-20\%. Jednak w warunkach sprzyjających patogenom spadek plonu może dochodzić do $70-80 \%$, a nawet $100 \%$ (Jajor i Mrówczyński 2013).

Najgroźniejsze choroby rzepaku to między innymi: zgorzel siewek (powodowana przez kompleks patogenów: Pythium spp., Rhizoctonia solani, Fusarium spp.), sucha zgnilizna kapustnych (Phoma lingam), czerń krzyżowych (Alternaria spp.), zgnilizna twardzikowa (Sclerotinia sclerotiorum), czy szara pleśń (Botrytis cinerea).

Do ograniczenia nasilenia objawów chorób powodowanych przez grzyby stosowane są fungicydy, które są skuteczne, jednak mogą stanowić zagrożenie dla zdrowia konsumenta wynikające $\mathrm{z}$ obecności pozostałości środków ochrony roślin i ich produktów rozkładu w użytkowanych częściach roślin, prowadzić do obciążenia środowiska oraz przy niewłaściwym doborze uodparniania patogenów.

W ostatnich latach wzrosło zainteresowanie troską o naturalne środowisko, dlatego poszukuje się alternatywnych sposobów walki z patogenami.

Szczególną uwagę poświęca się związkom pochodzenia naturalnego, ponieważ wydają się bardziej bezpieczne, biodegradowalne i efektywne w ograniczaniu patogenów, zwłaszcza grzybów i bakterii. Do takich związków zaliczają się wyekstrahowane z roślin olejki eteryczne wykazujące właściwości przeciwbakteryjne, przeciwgrzybiczne i owadobójcze (Survilienè i wsp. 2009). Są one złożonymi mieszaninami monoterpenów, monoterpenoidów, seskwiterpenów i substancji zapachowych, takich jak: estry, ketony, fenole, alkohole, etery, kumaryny, aldehydy, węglowodory i kwasy organiczne. Związki te skutecznie, w zakresie od 46 do $100 \%$ ograniczają rozwój wielu patogenów, takich rodzajów jak: Fusarium, Stemphylium, Botrytis, Aspergillus, Sclerotinia, Alternaria, Phytophthora, Sporotrichum i Penicillium (Kilmach i wsp. 1996; Orlikowski 2003; Burgieł i Smagłowski 2008; Survilienė i wsp. 2009; Krzyśko-Łupicka i Walkowiak 2014). Niektóre olejki, np. tymiankowy hamują także wydzielanie mykotoksyn (Soliman i Badeaa 2002).

Skuteczność olejków w hamowaniu wzrostu i rozwoju mikroorganizmów patogenicznych uzależniona jest od ich składu chemicznego, stężenia oraz wrażliwości samych patogenów, stąd pomysł wykorzystania olejków jako skutecznych biofungicydów w ochronie rzepaku.

Celem badań było określenie fungistatycznego stężenia wybranych olejków eterycznych wobec znanych grzybów patogenicznych rzepaku.

\section{Materiały i metody / Materials and methods}

Materiałem badań były izolaty grzybów pochodzące z kolekcji mikroorganizmów patogenicznych dla roślin Instytutu Ochrony Roślin - Państwowego Instytutu Badawczego, wyosobnione $\mathrm{z}$ roślin rzepaku ozimego z objawami chorobowymi. Izolaty były przechowywane pod olejem mineralnym $\mathrm{w}$ temperaturze $16^{\circ} \mathrm{C}$. Przed użyciem patogeny były ożywione i dwukrotnie pasażowane na podłożu PDA (Potato Dextrose Agar). Wybranymi grzybami były: Sclerotinia sclerotiorum (1998 i 2182), Phoma lingam (2283), Rhizoctonia solani (1924) i Fusarium oxysporum (1928).

Do badań wybrano olejki eteryczne marki Avicenna Oil: tymiankowy, grejpfrutowy, rozmarynowy, geraniowy, z trawy cytrynowej i z drzewa herbacianego. Olejki rozcieńczano w alkoholu etylowym uzyskując stężenia: 0,2; 0,02; 0,002 i 0,0002\%.

Aktywność biologiczną testowanych olejków oceniano metodą krążkowo-płytkową opisaną przez Solimana i Badeaa (2002). Do schłodzonej $\left(45^{\circ} \mathrm{C}\right)$ pożywki PDA dodawano etanolowe roztwory olejków. Tak przygotowaną pożywkę wylewano do szalek Petriego o średnicy $10 \mathrm{~cm}$. Do inokulacji pożywki użyto krążki o średnicy $5 \mathrm{~mm}$ pobrane z brzegu 10-dniowych kultur grzybów. Kontrolę negatywną stanowiła kultura wyszczepiona na podłożu bez olejków eterycznych oraz na podłożu z dodatkiem alkoholu.

Aktywność fungistatyczną testowanych olejków oceniano na podstawie procentu zahamowania wzrostu kolonii grzybów obliczonego ze wzoru Abbotta (Borecki 1984):

$$
\mathrm{I}=\frac{\mathrm{K}-\mathrm{A}}{\mathrm{K}} \times 100 \%
$$

I - współczynnik zahamowania wzrostu liniowego grzyba - stymulacji wzrostu,

$\mathrm{K}$ - średnica kolonii grzyba na płytce kontrolnej [mm],

$\mathrm{A}$ - średnica kolonii grzyba na płytce $\mathrm{z}$ określonym stężeniem olejku [mm].

Każdy wariant wykonano w 4 powtórzeniach. Pomiary średnicy kolonii i wyliczanie indeksu tempa wzrostu grzybni w temperaturze $24^{\circ} \mathrm{C}$ wykonano po 3 , 5 i 7 dniach. Wyniki przedstawione na wykresach odnoszą się do ostatniego dnia pomiarów.

\section{Wyniki i dyskusja / Results and discussion}

Wrażliwość badanych grzybów zależała od rodzaju i stężenia zastosowanego olejku w pożywce. Najsilniejsze właściwości fungistatyczne wobec wszystkich testowanych grzybów wykazywały 4 olejki: geraniowy, tymiankowy, $\mathrm{z}$ drzewa herbacianego i z trawy cytrynowej, w stężeniu $0,2 \%$. W pozostałych kombinacjach zahamowanie wzrostu grzybów było mniej efektywne i najbardziej ujawniające się w pierwszych dniach prowadzonego doświadczenia.

Szczególnie wysoką aktywnością wyróżniały się olejki: tymiankowy i z trawy cytrynowej (rys. 1-5). Pierwszy z nich najskuteczniej (w 100\%) hamował wzrost wszystkich testowanych kultur w stężeniach 0,2 i 0,02\%. Drugi 


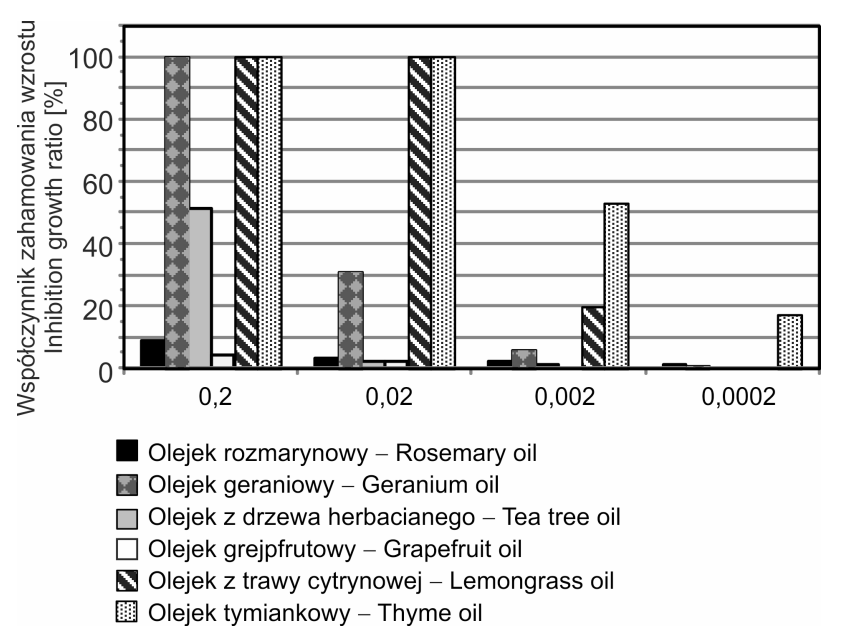

Rys. 1. Wpływ olejków eterycznych na wzrost grzybni Fusarium oxysporum 1928 [\%]

Fig. 1. Effect of essential oils on mycelial growth of Fusarium oxysporum 1928 [\%]

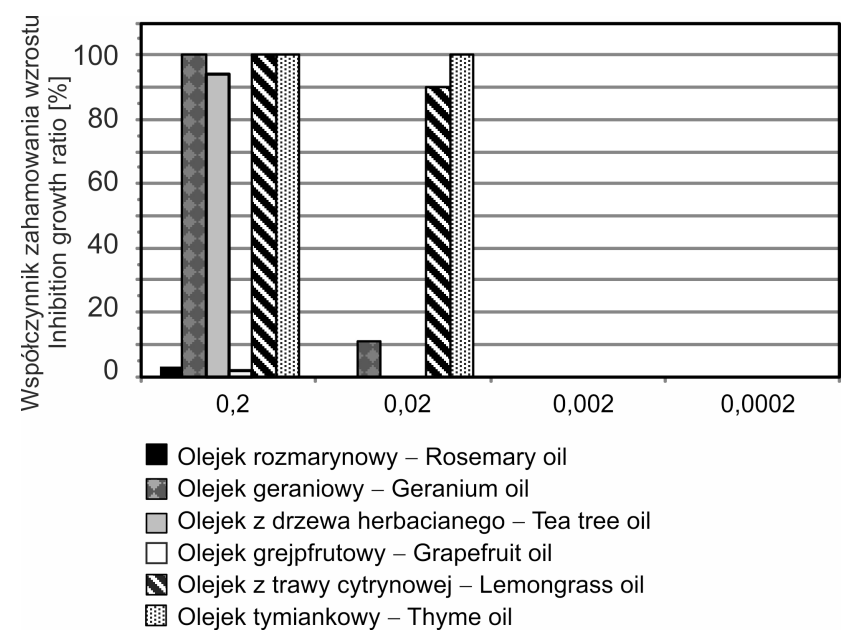

Rys. 2. Wpływ olejków eterycznych na wzrost grzybni Sclerotinia sclerotiorum 2182 [\%]

Fig. 2. Effect of essential oils on mycelial growth of Sclerotinia sclerotiorum 2182 [\%]

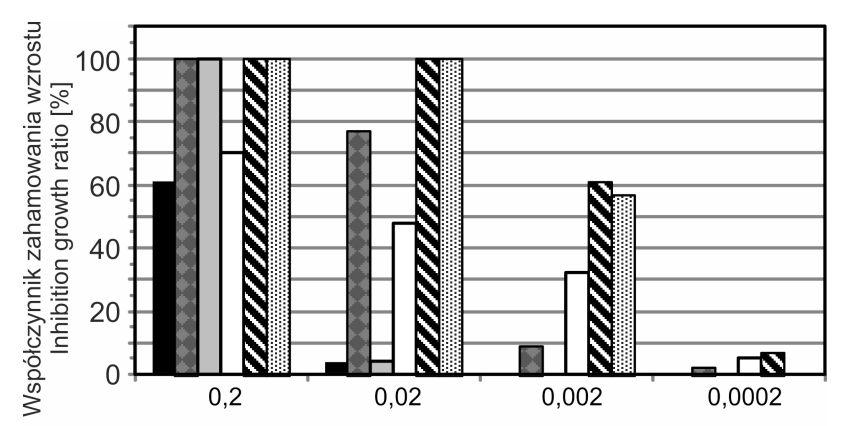

Olejek rozmarynowy - Rosemary oil Olejek geraniowy - Geranium oil

$\square$ Olejek z drzewa herbacianego - Tea tree oil

$\square$ Olejek grejpfrutowy - Grapefruit oil

D Olejek z trawy cytrynowej - Lemongrass oil

祭 Olejek tymiankowy - Thyme oil

Rys. 3. Wpływ olejków eterycznych na wzrost grzybni Phoma lingam 2283 [\%]

Fig. 3. Effect of essential oils on mycelial growth of Phoma lingam 2283 [\%]

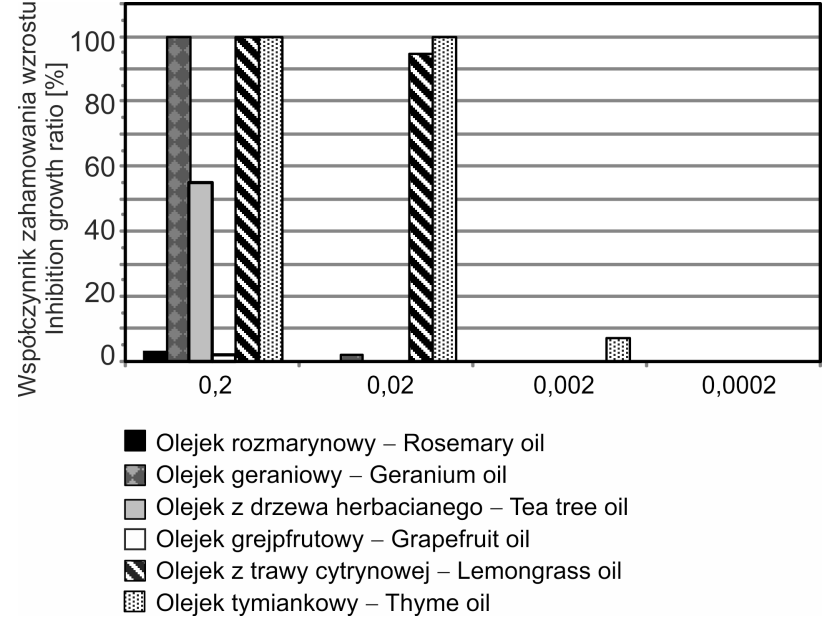

Rys. 4. Wpływ olejków eterycznych na wzrost grzybni Sclerotinia sclerotiorum 1998 [\%]

Fig. 4. Effect of essential oils on mycelial growth of Sclerotinia sclerotiorum 1998 [\%]

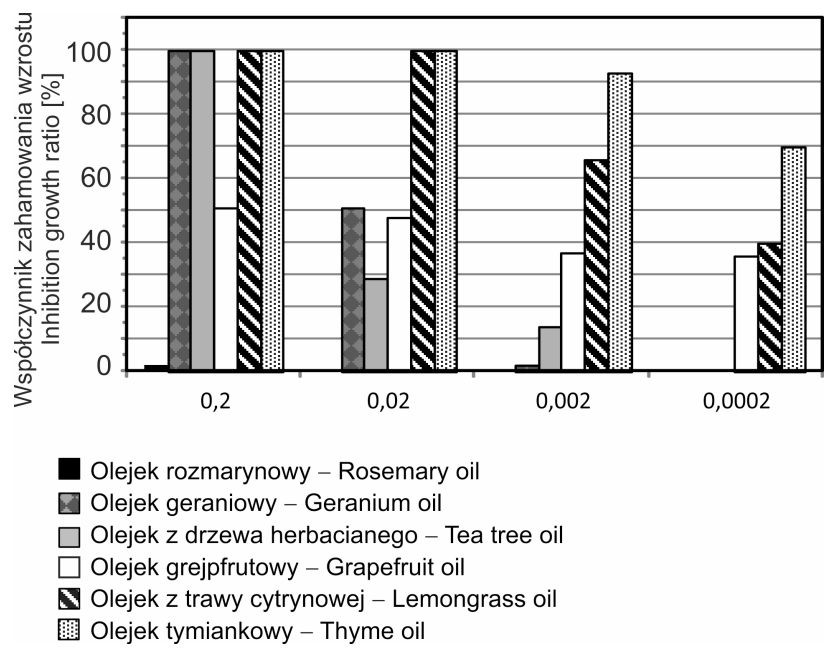

Rys. 5. Wpływ olejków eterycznych na wzrost grzybni Rhizoctonia solani 1924 [\%]

Fig. 5. Effect of essential oils on mycelial growth of Rhizoctonia solani 1924 [\%]

olejek w tych stężeniach całkowicie hamował wzrost F. oxysporum, $R$. solani i P. lingam (rys. 1, 3, 5).

Fungistatyczne działanie olejku z trawy cytrynowej, którego głównym składnikiem jest citral, potwierdzają badania Velluti i wsp. (2004) oraz Krzyśko-Łupickiej i Walkowiak (2014). Z kolei Ćosić i wsp. (2010) testując 11 olejków w stosunku do 12 grzybów patogenicznych wykazali, że olejek tymiankowy był najbardziej fungistatyczny obok cynamonowego, koniczynowego i anyżowego. Olejek tymiankowy całkowicie hamował wzrost Fusarium culmorum w stężeniu od 0,025 do 2,0\% (Krzyśko-Łupicka i Walkowiak 2014) oraz wykazywał silne właściwości hamujące wobec Alternaria alternata zarówno w warunkach in vitro, jak i in vivo (Feng i wsp. 2011). Potwierdzają to również badania Kręcidło i Krzyśko-Łupickiej (2015), w których olejek tymiankowy w stężeniu $1 \mathrm{~mm}^{3} / \mathrm{cm}^{3}$ w 100\% zahamował wzrost grzybów Trichoderma viride, Rhizomucor miehei i Penicillium spp. 
Olejek tymiankowy cechuje się podobną aktywnością inhibicyjną w stosunku do patogenów, jak chemiczne środki Funaben T i Ridomil 25 WP. W stężeniu 0,05; 0,1 i 0,2\% obserwowano całkowite zahamowanie wzrostu Fusarium sulphureum i Pythium spp. (Klimach i wsp. 1996).

Olejek geraniowy także charakteryzował się wysoką aktywnością fungistatyczną $(100 \%)$ wobec wszystkich testowanych szczepów, ale tylko w stężeniu $0,2 \%$. W niższej koncentracji w podłożu $(0,02 \%)$ aktywność fungistatyczna olejku spadała poniżej 30\%. Wyjątek stanowiły izolaty $P$. lingam i $R$. solani, które w tym stężeniu były hamowane odpowiednio w 77 i 50\% (rys. 3). Aktywność olejku geraniowego potwierdzono wobec wielu grzybów pleśniowych, między innymi rodzaju Aspergillus. Udowodniono także wpływ olejku geraniowego na hamowanie wytwarzania przez szczepy Aspergillus flavus i Aspergillus parasiticus aflatoksyny $\mathrm{B}_{1}$ - silnego karcynogenu (Kalemba i Kunicka 2003; Pawar i Thaker 2006).

Olejek rozmarynowy wykazywał najsłabsze właściwości fungistatyczne wobec testowanych izolatów. W najwyższym testowanym stężeniu olejek ograniczał jedynie wzrost $P$. lingam w $61 \%$ (rys. 3 ). Inne badania wskazują na jego dobrą skuteczność fungistatyczną wobec grzybów rodzaju Fusarium (Bartyńska i Budzikur-Ramza 2001; Survilienè i wsp. 2009).

Mało skuteczny okazał się olejek grejpfrutowy, który w stężeniu $0,2 \%$ hamował wzrost $R$. solani i $P$. lingam w zakresie 50-70\%. Wobec pozostałych izolatów nie wykazywał działania fungistatycznego. Pomimo, że olejek ten w niewielkim stopniu hamował wzrost badanych grzybów, zauważono, że w pierwszych dniach doświadczenia spowalniał ich rozwój.

Olejek grejpfrutowy wykazywał również najsłabsze właściwości fungistatyczne w doświadczeniach Krzyśko-Łupickiej i Walkowiak (2014), gdzie jego aktywność notowana była tylko w wyższych stężeniach (1-2\%). Mimo to, olejek grejpfrutowy znany jest z silnego hamowania wzrostu Phytophthora ramorum i Phytophthora cryptogea (Orlikowski 2001, 2003). Jest również składnikiem biopreparatu Biosept 33 SL (Cintamani Polska), który wykazuje długotrwałe działanie hamujące wobec wielu gatunków rodzaju Fusarium oraz B. cinerea, A. alternata i Trichoderma hamatum (Jamiołkowska 2011).

$\mathrm{W}$ przeprowadzonym doświadczeniu olejek $\mathrm{z}$ drzewa herbacianego charakteryzował się wysoką aktywnością inhibicyjną (powyżej 50\%) w stosunku do wszystkich przebadanych grzybów. Jednak w niższych stężeniach (poniżej 0,02\%) nie był już skuteczny wobec wszystkich testowanych izolatów z wyjątkiem $R$. solani (rys. 5). Z badań Burgieła i Smagłowskiego (2008) wynika, że olejek $\mathrm{z}$ drzewa herbacianego hamował wzrost $F$. culmorum i $B$. cinerea przy koncentracjach $0,001-0,1 \%$, a w stężeniu $0,3 \%$ powodował pełne zahamowanie wzrostu tych patogenów. W niższych stężeniach jego działanie było słabsze i obserwowane tylko w pierwszych dniach prowadzonego doświadczenia. Podobne wyniki uzyskali Bralewski i wsp. (2007) wobec Colletotrichum lindemuthianum i A. alterna- ta oraz Krzyśko-Łupicka i Walkowiak (2014) wskazując hamujący wpływ olejku z drzewa herbacianego na wzrost F. culmorum tylko przy stężeniu $0,25 \%$. Składnikiem odpowiedzialnym za fungistatyczne właściwości tego olejku jest 1-terpinen-4-ol (Terzi i wsp. 2007).

Oba izolaty $S$. sclerotiorum były najmniej wrażliwe na fungistatyczne działanie olejków eterycznych. Tylko olejek tymiankowy i z trawy cytrynowej w stężeniach 0,2 i $0,02 \%$ hamowały wzrost grzybni na poziomie 90-100\% (rys. 2, 4). W niższych stężeniach olejki te nie ograniczały wzrostu patogena.

S. sclerotiorum okazała się także najmniej wrażliwa na inhibicyjne działanie olejków eterycznych z Zataria multiflora, Thymus vulgaris i Thymus kotschyanus (Aminii wsp. 2012).

$P$. lingam i $R$. solani najsilniej reagowały na działanie większości przebadanych olejków. W przypadku pierwszego patogena wszystkie olejki w stężeniu 0,2\% zahamowały jego wzrost w zakresie od 60 do $100 \%$ (rys. 3). Olejki z trawy cytrynowej, tymiankowy i grejpfrutowy w niższym stężeniu $(0,002 \%)$ także ograniczały wzrost tego izolatu (> 30\%).

W przypadku $R$. solani te same olejki wstrzymały wzrost grzybni na poziomie co najmniej 30\% w najniższym przebadanym stężeniu, tj. 0,0002\%. Nieskuteczny w stosunku do tego izolatu był tutaj jedynie olejek rozmarynowy, który w stężeniu $0,2 \%$ nie hamował rozwoju strzępek na pożywce (rys. 5).

Zastosowanie olejków eterycznych jako środków grzybobójczych wymaga dalszych badań. Godne uwagi są: niska toksyczność względem ludzi i środowiska wynikająca $\mathrm{z}$ ich naturalnego pochodzenia oraz niskie ryzyko uodparniania mikroorganizmów patogenicznych na fungicydy (Daferera i wsp. 2000). Skłania to naukowców do poszukiwania alternatywnych związków grzybobójczych/ /bakteriobójczych, w tym przeznaczonych do zaprawiania nasion. Olejki o najsilniejszych właściwościach grzybobójczych znalazły zastosowanie głównie w rolnictwie ekologicznym lub jako składniki biopreparatów. Wykorzystanie ich $\mathrm{w}$ sadownictwie czy rolnictwie to dobrze prognozujące narzędzie ochrony roślin stanowiące element integrowanej produkcji roślin.

\section{Wnioski / Conclusions}

1. Olejek tymiankowy i z trawy cytrynowej w stężeniu 0,2 i $0,02 \%$ odznaczały się najsilniejszą aktywnością fungistatyczną w stosunku do wszystkich testowanych grzybów.

2. Olejek rozmarynowy wykazywał najsłabszą skuteczność i najmniej efektywnie ograniczał wzrost wszystkich testowanych izolatów.

3. Olejki: geraniowy, tymiankowy, z drzewa herbacianego i z trawy cytrynowej wykazywały bardzo dobrą skuteczność i najefektywniej ograniczały wzrost i rozwój szczepów $R$. solani i P. lingam. 


\section{Literatura / References}

Amini M., Safaie N., Salmani M.J., Shams-Bakhsh M. 2012. Antifungal activity of three medicinal plant essential oils against some phytopathogenic fungi. Trakia Journal of Sciences 10 (1): 1-8.

Banaszkiewicz T., Borkowska K. 2006. Ocena wybranych cech fizykochemicznych oraz zawartości energii metabolicznej nasion rzepaku w aspekcie ich wielkości. Rośliny Oleiste - Oilseed Crops 27: 367-376.

Bartyńska M., Budzikur-Ramza R. 2001. The action of some essential oils on fungi. Bulletin of the Polish Academy of Sciences, Serie Biological Sciences 49 (4): 327-331.

Borecki Z. 1984. Fungicydy stosowane w ochronie roślin. PWN, Warszawa, 173 ss.

Bralewski T.W., Frąckowiak M., Kozera-Stochaj L. 2007. Effect of selected aromatic oils on the development of pathogenic fungi colonizing vegetable seeds in the laboratory conditions. Bulletin of the University of Agricultural Sciences and Veterinary Medicine Cluj-Napocanr 64.

Burgieł Z.J., Smagłowski M. 2008. Fungistatyczne właściwości olejku z drzewa herbacianego. Zeszyty Problemowe Postępów Nauk Rolniczych 529: 13-18.

Ćosić J., Vrandečić K., Poštić J., Jurković D., Ravlić M. 2010. In vitro antifungal activity of essential oils on growth of phytopathogenic fungi. Poljoprivreda 16 (2): 25-28.

Daferera D.J., Ziogas B.N., Polissiou M.G. 2000. GC-MS analysis of essential oils from some greek aromatic plants and their fungitoxicity on Penicillium digitatum. Journal of Agricultural and Food Chemistry 48 (6): 2576-2581.

Feng W., Chen J., Zheng X., Liu Q. 2011. Thyme oil to control Alternaria alternata in vitro and in vivo as fumigant and contact treatments. Food Control 22 (1): 78-81.

Jajor E., Mrówczyński M. (red.). 2013. Metodyka integrowanej ochrony rzepaku ozimego i jarego dla producentów. Instytut Ochrony Roślin - Państwowy Instytut Badawczy, Poznań, 68 ss.

Jamiołkowska A. 2011. Laboratory effect of azoxystrobin (Amistar 250 SC) and grapefruit extract (Biosept 33 SL) on growth of fungi colonizing zucchini plants. Acta Scientiarum Polonorum, Hortorum Cultus 10 (2): 245-257.

Kalemba D., Kunicka A. 2003. Antibacterial and antifungal properties of essential oils. Current Medicinal Chemistry 10 (10): $813-829$.

Kilmach A., Wieczorek W., Góra J. 1996. Wpływ olejków eterycznych na ograniczenie występowania niektórych chorób grzybowych i bakteryjnych roślin. Pestycydy 1: 45-54.

Kręcidło Ł., Krzyśko-Łupicka T. 2015. Wrażliwość grzybów wyizolowanych z magazynów zakładu przemysłu spożywczego na wybrane olejki eteryczne. Inżynieria Ekologiczna Ecological Engineering 43: 100-108. DOI: 10.12912/23920629/58910.

Krzyśko-Łupicka T., Walkowiak W. 2014. Evaluation of susceptibility of phytopathogenic Fusarium culmorum strain on selected essential oils. Ecological Chemistry and Engineering A 21 (3): 355-366.

Orlikowski L.B. 2001. Effect of grapefruit extract on development of Phytophthora cryptogea and control of food rot of gerbera. Journal of Plant Protection Research 41 (3): 288-294.

Orlikowski L.B. 2003. Development and spread of Phytophthora ramorum in the presence of grapefruit extract. Journal of Plant Protection Research 43 (3): 213-218.

Pawar V.C., Thaker V.S. 2006. In vitro efficacy of 75 essential oils against Aspergillus niger. Mycoses 49 (4): 316-323. DOI: 10.1111/j. .1439-0507.2006.01241.x.

Soliman K.M., Badeaa R.I. 2002. Effect of oil extracted from some medicinal plants on different mycotoxigenic fungi. Food and Chemical Toxicology 40 (11): 1669-1675.

Survilienė E., Valiuškaitė A., Snieškienė V., Stankevičienė A. 2009. Effect of essential oils isolated from apples and vegetables. Scientific works of the Lithuanian Institute of Horticulture and Lithuanian University of Agriculture. Sodininkystė ir Daržininkystė 28 (3): 228-234.

Terzi V., Morcia C., Faccioli P., Valè G., Tacconi G., Malnati M. 2007. In vitro antifungal activityof the tea tree (Melaleuca alternifolia) essential oil and its major components against plant pathogens. Letters in Applied Microbiology 44 (6): 613-618. DOI: 10.1111/j.1472-765X.2007.02128.x.

Velluti A., Marin S., Gonzales P., Ramos A., Sanchis V. 2004. Initial screening for inhibitory activity of essential oils on growth of Fusarium verticillioides, F. proliferatum and F. graminearum on maize-based agar media. Food Microbiology 21 (6): $649-656$. 